\title{
The Effect of Word of Mouth on Buying Interests through Trust in Cukli Creative Industries on Lombok Island
}

\author{
Uji Alvian; Dwi Putra Buana Sakti; Lalu M. Furkan
}

Faculty of Economics and Business, Master of Management Study Program, Mataram University, Indonesia

Email: b4134r@gmail.com

http://dx.doi.org/10.47814/ijssrr.v5i3.175

\begin{abstract}
Small and medium enterprises (SMEs) is one of the supporting economic growths of a region. Small and medium-sized businesses can be developed by increasing the buying interest of the people around. This research was conducted to find out the effect of Word of Mouth on buying interests and to find out the influence of Word of Mouth on trust, to find out the influence of trust on buying interests and to find out the influence of Word of Mouth on buying interests through trusts. This research was conducted in locations namely West Lombok Regency and Mataram City. The population in the study is people who have bought Cukli in two regencies in West Nusa Tenggara Province, namely West Lombok Regency located in Gunung Sari District, namely Sesela Village and in Mataram City, which is located in Cakra District, Sayang-Sayang Art Market, Rungkang Jankok Village and Lendang Re Village. Analysis of the data used is PLS with the results of the study showing that Word of Mouth has a positive effect on buying interest. Word of Mouth has a positive effect on trust. Trusts have a positive effect on buying interest and Word of Mouth has a positive effect on buying interest through trusts.
\end{abstract}

Keywords: Cukli; Small and Medium Enterprises; Word of Mouth; Buying Interests; Trust

\section{Introduction}

Small and medium enterprises (SMEs) is one of the supporting economic growths of a region. With the rapid competition of the business world today, SMEs are required to increase local competitiveness by improving, preparing themselves and trying to win this competition (Ulum, 2010). Small and medium-sized businesses can be developed by increasing the buying interest of the people around. Buying interest creates a motivation that continues to be recorded in the minds of consumers and becomes a very strong desire that in the end when a consumer must meet his needs will actualize what is in his mind. Many ways that marketers do in promoting various products to be able to bring stimulus to attract the attention of consumers, one of which is Word of Mouth.

Word of mouth is a form of promotion in the form of recommendations and spread by word of mouth about the advantages of a product (Lupiyoadi, 2013). WOM occurs when a consumer talks about his or her opinion of a product or service to another person (Athar, 2020). In addition, the person who conveys WOM is considered to only provide information and share his experience in consuming a product/service without having any interest in the sale of the product/service. 
Consumer confidence is the expectation of consumers that service providers can be trusted and relied upon in fulfilling their promises (Siagian and Cahyono, 2014; Anggriani and Athar, 2017). Trust itself is a catalyst in various transactions between sellers and buyers so that consumer satisfaction can be realized and consequently will have an impact on higher purchasing decisions (Yousfazai, et al., 2003). Research conducted by Sitorus and Hartono, (2015) on the effect of custommer trust mediation on the influence of Word of Mouth, perceived quality, brand image on purchase intention. The results of the study prove that first; Word of Mouth has a positive and significant effect on customer trust.

The creative industry is one of the economic supports of the community in West Nusa Tenggara Province precisely in West Lombok Regency located in Gunung Sari Subdistrict namely Sesela Village and in Mataram City which is located in Cakra District, Sayang-Sayang Art Market, Rungkang Jankok Village and Lendang Re Village. Of the 14 sub-sectors in the creative industry, one of them is the craft creative industry which is the mainstay of the people of West Lombok Regency and Mataram City.

In 2016 the production volume of Cukli Craft Industry (CCI) artisans in West Lombok Regency and Mataram City reached 7800 to 8200 units sold per year and in 2017 experienced a not-so-significant decline, but the volume of their production business decreased very drastically due to natural disasters in 2018 until many CCI Cukli entrepreneurs experienced losses to not be able to produce until some went out of business. In 2019 they CCI Cukli pilgrims bounced back but in early 2020 again reduced their production, even most of them did not produce because of the outbreak that hit the world, namely the Covid-19 Virus. Then from the cukli capacity graph above can be indicated that cukli craftsmen are lacking in utilizing various means to increase buying interest including word of mouth (WOM) which can be used as a marketing communication strategy. WOM makes the buying interest process faster, because what is talked about in WOM is based on the experience of cukli products so that consumers will tend to trust it. Word of mouth can also play a role more because it can increase consumer confidence because the information that is embraced through word of mouth is obtained from third parties.

\section{Literature Review}

\section{Buying Interest}

Schiffman and Kanuk (2007) buying interest is the behavior of consumers who have a desire to buy a product or take actions related to the purchase of a particular product. While Setiadi (2003) stated that buying interest is formed from consumer attitudes towards brands and brand evaluation, so that from these two stages comes interest in buying.

\section{Trust}

Trust itself is a catalyst in various transactions between sellers and buyers so that consumer satisfaction can be realized and consequently will have an impact on higher purchasing decisions (Yousfazai, et al, 2003). According to Mayer, et al., (1995) trust is a person's willingness to be sensitive to the actions of others based on the expectation that others will perform certain actions on people who trust them, without depending on his ability to supervise and control.

\section{Wom}

Word of mouth is a form of promotion in the form of recommendations and spread by word of mouth about the advantages of a product (Lupiyoadi, 2013). WOM occurs when a consumer talks about his or her opinion of a product or service to another person. Consumers who spread information about the goodness of the product are referred to as positive WOM, but if the consumer disseminates information about the badness of the product it is referred to as negative WOM (Brown, et.al., 2001). 


\section{Conceptual Framework of Research}

Based on the background of the problem, the conceptual results of this study are as follows:

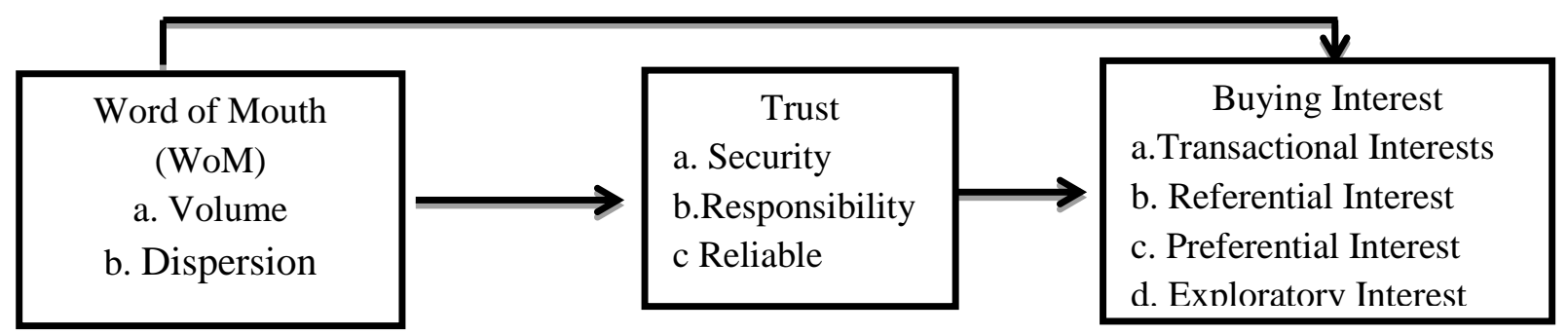

Figure 1. Conceptual Framework of Research

\section{Research Methodology}

\section{Population and Research Samples}

According to Sugiyono, (2011) population is a generalization area consisting of: objects / subjects that have certain qualities and characteristics set by researchers to be studied and then drawn conclusions. The population of this study is people who have known Cukli information in the Creative Industries of Lombok Island. Therefore, the researcher did not know the clear population, so the researcher concluded that taking a population of 100 respondents, this is based on the ability of researchers seen from time, energy and cost and this is also based on the opinion of Hair, Anderson, Tatham, \& Black, (2010) the size of the sample if it is too large will make it difficult to get a suitable model, and suggested the appropriate sample size between 100-200 respondents in order to be used interpretation estimates. Structural Equation Model (SEM).

Sampled in this study with the following criteria. People have known Cukli information located in the area of West Nusa Tenggara Province, namely West Lombok Regency located in Gunung Sari Subdistrict namely Sesela Village and in Mataram City which is located in Cakra Subdistrict, SayangSayang Art Market, Rungkang Jankok Village and Lendang Re Village.

\section{Validity and Reliability Test Results}

The results of the research questionnaire validity test for variables as seen in Table 1.

Table 1. Outer Loadings (Measurement Model)

\begin{tabular}{|c|c|c|c|}
\hline No & Variable & Items & Outer Loadings \\
\hline \multirow{4}{*}{1} & \multirow{3}{*}{ Word of Mouth (X1) } & $\mathrm{X} 1.1$ & 0.84 \\
\cline { 3 - 4 } & & $\mathrm{X} 1.2$ & 0.80 \\
\cline { 3 - 4 } & & $\mathrm{X} 1.3$ & 0.70 \\
\cline { 3 - 4 } 2 & & $\mathrm{X} 1.4$ & 0.63 \\
\hline \multirow{3}{*}{3} & \multirow{3}{*}{ Trust (X2) } & $\mathrm{X} 2.1$ & 0.91 \\
\cline { 3 - 4 } & & $\mathrm{X} 2.2$ & 0.91 \\
\cline { 3 - 4 } & & $\mathrm{X} 2.3$ & 0.89 \\
\cline { 3 - 4 } & \multirow{3}{*}{ Buying Interest (Y) } & $\mathrm{Y} 1.1$ & 0.88 \\
\cline { 3 - 4 } & & $\mathrm{Y} 1.2$ & 0.89 \\
\cline { 3 - 4 } & & $\mathrm{Y} 1.3$ & 0.83 \\
\hline
\end{tabular}

Source: Primary Data Processed in 2021 
Based on the table of outer loadings above it can be seen that all items of the indicator on the Word of Mouth variable, trust, and buying interest have an outer loadings value above 0.5 so that all indicator items can be used in research without any indicators being dropped. Variables are said to have high reliability if the composite reliability value is above 0.70 . In Table 2 will be presented composite reliability value:

Table 2. Composite Reliability Value

\begin{tabular}{|l|c|}
\hline \multicolumn{1}{|c|}{ Variable } & Composite Reliability \\
\hline Word of Mouth & 0.929 \\
\hline Trust & 0.866 \\
\hline Buying Interest & 0.929 \\
\hline
\end{tabular}

Source: Primary Data Processed in 2021

The composite reliability value shown in Table 3.2. The above for each construct indicates that the Word-of-Mouth construct, trust construct and buying interest construct are reliable.

\section{Results of PLS Analysis}

To assess the significance of the predictive model in structural model testing, it can be seen from the t-statistical value between independent variables to dependent variables in the Path Coefficient table in SmartPLS output below:

Table 3. Relationships Between Variables

\begin{tabular}{|c|l|c|c|c|}
\hline No & Relationships Between Variables & Coefficient Line & T-statistics & Conclusion \\
\hline 1 & Word of Mouth $(\mathrm{X} 1) \rightarrow$ Minat beli $(\mathrm{Y})$ & 0.284 & 13.374 & Significant \\
\hline 2 & Word of Mouth $(\mathrm{X} 1) \rightarrow$ Trust $(\mathrm{X} 2)$ & 0.665 & 12.012 & Significant \\
\hline 3 & Trust $(\mathrm{X} 2) \rightarrow$ Buying interest $(\mathrm{Y})$ & 0.552 & 6.878 & Significant \\
\hline
\end{tabular}

Source: Primary Data Processed in 2021

\section{Hypothesis Testing 1: The Effect of Word of Mouth On Buying Interests}

Hypothesis 1 states that Word of Mouth has a significant positive effect on buying interest. Test results on the parameter coefficient between Word of Mouth and buying interest showed a positive influence with a coefficient value of 0.284 but with a t statistical value of 13,374 showed a significant effect. The t statistical value is above the critical value of 1,680 , thus Ha is accepted. This shows that Word of Mouth has a positive effect on buying interest and its influence is significant.

\section{Hypothesis Testing 2: The Effect of Word of Mouth On Trust}

Hypothesis 2 states that Word of Mouth has a significant positive effect on trust. Test results on the parameter coefficient between Word of Mouth and trust showed a positive influence with a coefficient value of 0.665 and a t-statistic value of 12.012 showing a significant effect. The t-statistic is above the critical value of 1,680, thus Ha is accepted. This shows that Word of Mouth has a positive and significant effect on trust. 


\section{Hypothesis Testing 3: The Effect of Trust On Buying Interest}

Hypothesis 3 states that trusts have a significant positive effect on buying interest. The test results on the parameter coefficient between trusts to buying interest showed a positive influence with a coefficient value of 0.552 and a $t$ statistical value of 6.878 showing a significant effect. The $t$-statistic is above the critical value of 1,680 , thus $\mathrm{Ha}$ is accepted. This shows that trusts have a positive and significant effect on buying interest.

\section{Results and Discussions}

\section{The Effect of Word of Mouth On Buying Interest}

The results of the data analysis showed that Word of Mouth had a positive and significant effect on buying interest. So hypothesis 1 which states "Word of Mouth has a significant positive effect on buying interest" is accepted. This means that the better Word of Mouth is done, it will increase respondents' buying interest in the products offered.

This research proves that using Word of Mouth can significantly increase buying interest. This is because through Word of Mouth they can receive testimonials of the products they want more clearly from the side of their fellow users, as well as the experience felt when using the product.

The results are in line with research conducted by Gabriel and Kolapo, (2015) which found that Word of Mouth has a positive and significant influence on consumer buying interest in companies in Nigeria. According to Kotler and Keller, (2009) buying interest is derived from a learning process and thought processes that form a perception. This buying interest creates a motivation that continues to be recorded in the minds of consumers and becomes a very strong desire that in the end when a consumer must meet his needs will actualize what is in his mind. For that reason, according to Silverman, (2011) that word of mouth becomes important because it can generate independent trust because it gets it from third parties.

\section{The Effect of Word of Mouth On Trust}

The results of the data analysis showed that Word of Mouth had a positive and significant effect on trust. So hypothesis 2 which states "Word of Mouth with Instagram has a significant positive effect on trust" was accepted. This means that the better Word of Mouth is done, it will increase public trust or trust in the products offered.

The results of this study showed, by using Word of Mouth can increase public trust. According to Hajli, (2013) Word of Mouth can increase a person's confidence in the products seen. This is because through Word of Mouth they will be able to build testimonials that will be able to affect each other's perceptions. Especially when they get the experience or experience of shopping and using from other consumers it will be very quickly and easy to tell the experience. According to Ganesan, (1994) in Siagian and Cahyono, (2014) trust or trust is interpreted as credibility to the extent to which buyers believe that suppliers or sellers have the expertise to carry out activities effectively and reliably. According to Mukherjee and Nath, (2015) by building trust, sellers will build a closer relationship with consumers and this will result in consumers to re-buy the products offered. So, this will make the seller will be more careful in offering his products. 


\section{The Effect of Trust On Buying Interest}

The results of the data analysis showed that trusts have a positive and significant effect on buying interest. So hypothesis 3 which states "trusts have a significant positive effect on buying interest" is accepted. This means that the higher the trust of the community, it will increase people's buying interest in the products offered.

According to Kinnear and Taylor, (1995), buying interest is the level of consumer tendency to act before a buying decision is actually made. The purchase intention is at the stage of the buying process. Buying interest is obtained from a learning process and thought processes that form a perception. So it is important for sellers to instill a good perception to their consumers.

This research is in line with research conducted by Hajli, (2013) has the result that trusts have a positive and significant effect on consumer buying interest. According to Sujana and Suprapti, (2016) the higher consumer confidence, the higher the purchase intentions that will be made by these consumers. This buying interest creates a motivation that continues to be recorded in the minds of consumers and becomes a very strong desire that in the end when a consumer must meet his needs will actualize what is in his mind.

\section{The Effect of Word of Mouth On Buying Interests Through Trust}

Based on the results shown, the study states that buying interest is influenced by Word of Mouth with trust mediation. This is indicated by the Word of Mouth variable with trust mediation can affect buying interest with a path coefficient value of 0.367 . From these calculations, it means that there is an indirect influence between the Word of Mouth variable and the interest in buying through trust with a path coefficient value of 0.367 . Comparison of indirect influence of Word of Mouth with buying interest through trust with its direct influence between Word of Mouth and buying interest obtained a result of $0.367>0.284$ so that it can be stated that the trust serves as full mediation in the influence of Word of Mouth on buying interest. This means that Word of Mouth is not able to directly affect buying interest without going through trust.

This provides guidance to sellers that they must build and maintain the trust or trust of their consumers. So, the reputation they make through their service to customers who shop must be able to provide trust in the community and themselves first. Through Word of Mouth, they must be able to give the impression of good service and the appropriate quality of the product. This is important to be done by the seller in order to maintain and maintain the trust of its consumers.

According to Yousafzai, et al. (2003) trusts must really be a very important and main consideration as a catalyst in various transactions between sellers and buyers in order for consumer satisfaction to be realized and will make repurchases. If the seller does not build and maintain trust or consumer trust then consumers will easily tell about the ugliness of service to others and cause prospective customers to feel reluctant to shop in their stores. According to Aribowo and Nugroho, (2013) trust is the trust of the other party in conducting transaction relations based on a belief that the person he trusts will fulfill all his obligations properly as expected. So, it is very important for sellers to pay attention and maintain consumer confidence in their stores. The results of this study prove that sellers must keep trust from their consumers because without trust, Word of Mouth cannot increase consumer buying interest. 


\section{Conclusions}

Based on the results of research on the influence of Word of Mouth on buying interest with trust as an intevening variable, it can be concluded that: (1) Word of Mouth has a positive and significant effect on buying interest. This shows that when Word of Mouth is done well done, it will be able to increase people's buying interest; (2) Word of Mouth has a positive and significant effect on trust. This shows that word of mouth that sellers do well will be able to increase the trust of the community. So the more positive the information conveyed, the more trust consumers in a product will be; (3) Trusts have a positive and significant effect on buying interest. This shows that when the seller maintains the trust of the community or trust it will be able to increase the buying interest of the community; (4) Word of Mouth has a positive and significant effect on buying interest through trust. This shows that Word of Mouth has a positive effect on trust and will also have a positive effect on buying interest.

\section{References}

Anggriani, R., \& Athar, H. S. (2017). Pengaruh Sifat Materialisme, Motivasi Hedonik Terhadap Impulsive Buying Dan Kecenderungan Compulsive Buying Secara Online Di Kalangan Mahasiswa Universitas Mataram. JMM UNRAM-MASTER OF MANAGEMENT JOURNAL, 6(2).

Aribowo, D. P. ., \& Nugroho, M. A. (2013). Pengaruh Trust Dan Perceived Of Risk Terhadap Niat Untuk Bertransaksi Menggunakan E-Commerce. Jurnal Nominal, 1(3), 1-18.

Athar, H. S. (2020). The Effect of Electronic Word of Mouth in Social Media and Experiential Value on Destination Image Dan Revisit Intention after Earthquake in Lombok. Global Journal of Management and Business Research: E Marketing, 19(8-E).

Brown, M., Pope, N. \& Voges, K. (2001), "Buying or Browsing? An Exploration of Shopping Orientations and Online Purchase Intention”, European Journal ofMarketing, 37(11), 1666-1684.

Gabriel, J., \& Kolapo, S. (2015). Online Marketing and Consumer Purchase Behaviour: A Study of Nigerian Firms. British Journal of Marketing Studies, Vol. 3, No. 7, pp. 1-14

Hajli, N. 2013. A Study Of The Impact Of Social Media On Consumers. International Jorunal of Market Research. Vol. 56, pp: 387-404

Hair, J. F. Jr., Anderson., R. E. Tatham., R. L. \& Black. W. C. (2010). Multivariate Data Analysis. $5^{\text {th }}$ edition. New York: Prentice Hall.

Kotler, P., \& Keller, K.L., 2009. Manajemen Pemasaran. Edisi ke 13. Jakarta: Erlangga.

Kinnear, T.C. And Taylor, J.R. 1995. Marketing Research: An Applied Approach. McGraw Hill Text.

Lupiyoadi, R., 2013. Manajemen Pemasaran Jasa Berbasis Kompetensi. Edisi 3, Jakarta, Salemba Empat.

Mukherjee, A \& Nath, P. 2015. A Model of Trust In Online Relationship Banking. Journal of Bank Marketing. Vol. 5, pp: 5-15

Mayer, R. C., Davis, J. H., \& Schoorman, F. D. 1995. An integrative model of organizational trust. Academy of Management Review, 20, 709-734. 
Schiffman, L., dan Kanuk, L., 2007. Perilaku Konsumen. Edisi Kedua. Jakarta: PT. Indeks Gramedia.

Setiadi, N. J. (2003). Perilaku Konsumen Konsep dan Implikasi untuk Strategi dan Penelitian Pemasaran. Jakarta: Prenada Media

Sitorus, T., dan Hartono, R., 2015. Efek Mediasi Custommer Trust Atas Pengaruh Word Of Mouth. Perceived Quality, Brand Image Terhadap Purchase Intention. Jurnal Magister Manajemen, Vol.8,No.2, pp:58-91

Silverman, G., 2001. The Secrets of Word-of-mouth Marketing: How to Trigger Exponential Sales Through Runaway Word of Mouth. AMACOM Div

Siagian \& Cahyono. 2014. Analisis Website Quality, Trust Dan Loyalty Pelanggan Online Shop.Jurnal Manajemen Pemasaran, Vol.8 (2), 55-61.

Sugiyono. 2011. Metode Penelitian Kuantitatif Kualitatif dan R\&D, Bandung, Alfabeta.

Sujana, K \& Suprapti W S.2016.Peran Kepercayaan Dalam Memediasi Pengaruh Kualitas Situs Terhadap Niat Konsumen Untuk Berbelanja Di Situs Zalora.Jurnal Manajemen Unud, Vol 5 (1), 595-622.

Ulum, I, 2010. Akuntansi Sektor Publik, Graha Ilmu, Yogyakarta.

Yousafzai, S. Y., Pallister, J. G., dan Foxall, G. R., 2003. A Proposed Model of E-Trust for Electronic Banking, Technovation, 23: 847-860.

\section{Copyrights}

Copyright for this article is retained by the author(s), with first publication rights granted to the journal.

This is an open-access article distributed under the terms and conditions of the Creative Commons Attribution license (http://creativecommons.org/licenses/by/4.0/). 